\title{
Optimum oil palm planting density in West Africa
}

\author{
Xavier Bonneau ${ }^{1, *}$, Reinout Impens ${ }^{2}$ and Maxwell Buabeng ${ }^{2}$ \\ ${ }^{1}$ CIRAD, UPR Systèmes de Pérennes, 34398 Montpellier, France \\ 2 SIAT, Presco-Plc, km 22 Benin-Sapele road, P.O.B. 7061, Benin City, Edo State, Nigeria
}

Received 28 October 2017 - Accepted 29 December 2017

\begin{abstract}
This article follows on from an earlier one about the same experiment in 2014. A range of various planting distances (from 7.5 to 9.5 metres) between oil palms was tested using an equilateral triangle design. The current planting density experiment was set up in an oil palm plantation in Nigeria. The climatic conditions are quite stable, with two seasons and around $2000 \mathrm{~mm}$ of annual rainfall. The soil is of the desaturated ferralitic type, sandy on the surface, deep and without coarse elements. After twelve years of continual monitoring and extrapolation of the results obtained up to the end of the cycle, we concluded on an optimum planting density of between 143 and 160 oil palms per hectare in a monospecific, equilateral triangle planting design (i.e. a distance of 8.5 to 9 metres between palms). It will take another few years of yield recording to fine-tune the result. For 12year-old palms, this density range corresponds to a Leaf Area Index of 3.5 to 4, a light interception percentage of 89 to 90 and a foliage overlap percentage of 51 to 68. A thinning treatment was included in the protocol. Thinning at eight years has not led to any advantage after four years.
\end{abstract}

Keywords: oil palm / planting density / spacing / thinning / yield

Résumé - Densité de plantation optimale du palmier à huile en Afrique de l'ouest. Cet article fait suite à un précédent article publié en 2014 sur la même expérience. Une gamme de distances de plantation variables entre palmiers à huile (de 7,5 à 9,5 mètres) a été testée dans un dispositif en triangle équilatéral. L'expérience de densité de plantation en cours a été mise en place dans une palmeraie au Nigéria. Les paramètres climatiques locaux sont stables, avec deux saisons et environ $2000 \mathrm{~mm}$ de hauteur de précipitations annuelle. Le sol est du type ferrallitique désaturé : sableux en surface, profond et sans éléments grossiers. Après douze ans de suivi en continu et extrapolation des résultats jusqu'à la fin du cycle, nous avons conclu à une densité de plantation optimale comprise entre 143 et 160 palmiers à l'hectare dans un dispositif de culture monospécifique en triangle équilatéral (soit une distance de 8,5 à 9 mètres entre palmiers). Il faudra encore quelques années d'enregistrement de la production pour affiner le résultat. Pour des palmiers âgés de douze ans, cette densité de plantation correspond à un Indice Foliaire de 3,5 à 4, à un pourcentage d'interception radiative de 89 à 90 et à un pourcentage de recouvrement du feuillage de 51 à 68 . Un traitement: éclaircissage, était inclus dans le protocole. L'éclaircissage à huit ans n'a procuré aucun avantage après quatre ans.

Mots-clé : palmier à huile / densité de plantation / écartement / éclaircissage / rendement

\section{Introduction}

In an earlier article (Bonneau et al., 2014), we described how the planting density affected oil palm yields in the first eight years after planting. Since then, we have recorded the results of four more seasons at the adult age ( 9 to 12 years). This has enabled us to determine the planting density effect over a longer period, notably including some seasons where the leaf mass and span of the palms continued to increase. Based on these

\footnotetext{
*Correspondence: xavier.bonneau@cirad.fr
}

consolidated results, some simulations were carried out to determine the planting density effect over a complete cycle (20 to 25 years) and thereby ascertain the optimum density, or density range, under our experimental conditions.

\section{Materials and methods}

These were described in detail in the earlier article (Bonneau et al., 2014). As the same palms were involved, in the same place and in the same experimental design, only a brief reminder will be given again here. 


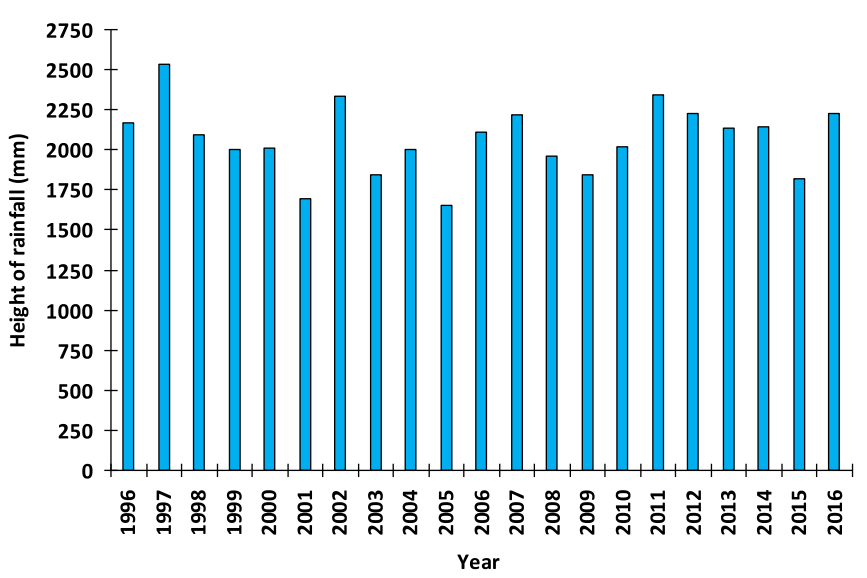

Fig. 1. Obaretin: annual rainfall (mm).

\subsection{Location, soil and climate}

The Presco Plc plantation is located at Obaretin near Benin City, Edo State in Nigeria. The terrain in the region is flat, over a vast sedimentary formation called the Continental Terminal. The very uniform soils are of a ferralitic type; they are deep, very sandy on the surface, with a gradual increase in clay content with depth, without any coarse elements. There are two seasons: a dry season from November to April (the driest months being December and January) and a wet season that occurs from May to October, providing an average annual rainfall of $2066 \mathrm{~mm}$ (Fig. 1). Rainfall is well distributed and a moderate water deficit occurs. The planting density experiment was set up in a second-generation plantation established in July 2005 , on previous oil palm cover that had occupied the plot for 25 years. The stems of the felled old palms were pushed to the edge of the experimental plot.

\subsection{Planting material}

The planting material used since 2002 by the Presco company is of the Pobè C1001F type, which belongs to the Deli x La Mé group. This variety is widely used all around the world as it is one of the best high-yielding material available in the world. It has a slow growth rate. In addition, this material has been bred for its resistance to Fusarium wilt: a fungal disease, which is widely present in Africa. Its high resistance to that disease has secured the investment of the African planters. This variety represents more than half of the oil palm acreage planted in Africa and it is expected to remain one of the most widely used material for the next 20 to 30 years.

\subsection{Statistical design}

Our statistical design is a randomized complete block with four replicates of six treatments as described in Table 1.

Each of the 24 unit plots comprises 72 palms, planted in 9 rows of 8 palms with a double border, i.e. 20 useful central palms (5 rows of 4 ). Where necessary, any gaps between the unit plots have been filled with neutral palms. The total area of the trial is 12.7 hectares.

The experimental palms are planted in an equilateral triangle design.
Table 1. Treatment description.

\begin{tabular}{llll}
\hline Treatment & $\begin{array}{l}\text { Initial planting } \\
\text { density (number } \\
\text { of palms per } \\
\text { hectare) }\end{array}$ & $\begin{array}{l}\text { Distance } \\
\text { between } \\
\text { palms } \\
\text { (in metres) }\end{array}$ & $\begin{array}{l}\text { Management } \\
\text { of planting } \\
\text { density }\end{array}$ \\
\hline D 1 & 128 & 9.5 & Fixed \\
D 2 & 143 & 9 & Fixed \\
D 3 & 160 & 8.5 & Fixed \\
D 4 & 180 & 8 & Fixed \\
D 5 & 180 & 8 & Thinned (1) \\
D 6 & 205 & 7.5 & Fixed \\
\hline
\end{tabular}

(1) By eliminating every 7 th palm at 8 years (one central palm per hexagon); at eight years (July 2013) the density went from 180 down to $154 \mathrm{p} / \mathrm{ha}$.

Table 2a. Fertilization applied since planting. Fertilization per palm on young palms (in $\mathrm{g}$ of fertilizer per palm).

\begin{tabular}{lllll}
\hline Date & \multicolumn{4}{c}{ Type of fertilizer } \\
\cline { 2 - 5 } & Compound & $\mathrm{KCl}$ & Kieserite & Borax \\
\hline July 2005 & 500 & $\mathrm{x}$ & $\mathrm{x}$ & $\mathrm{x}$ \\
September 2005 & 500 & $\mathrm{x}$ & $\mathrm{x}$ & $\mathrm{x}$ \\
April 2006 & 500 & $\mathrm{x}$ & $\mathrm{x}$ & $\mathrm{x}$ \\
September 2006 & 500 & $\mathrm{x}$ & $\mathrm{x}$ & $\mathrm{x}$ \\
March 2007 & 1000 & $\mathrm{x}$ & $\mathrm{x}$ & $\mathrm{x}$ \\
June 2007 & 1000 & $\mathrm{x}$ & $\mathrm{x}$ & $\mathrm{x}$ \\
September 2007 & 1000 & $\mathrm{x}$ & $\mathrm{x}$ & $\mathrm{x}$ \\
March 2008 & 2000 & $\mathrm{x}$ & $\mathrm{x}$ & $\mathrm{x}$ \\
October 2008 & $\mathrm{x}$ & $\mathrm{x}$ & 500 & $\mathrm{x}$ \\
May 2009 & $\mathrm{x}$ & 2000 & $\mathrm{x}$ & $\mathrm{x}$ \\
June 2009 & $\mathrm{x}$ & $\mathrm{x}$ & 500 & $\mathrm{x}$ \\
July 2010 & $\mathrm{x}$ & $\mathrm{x}$ & $\mathrm{x}$ & 50 \\
\hline
\end{tabular}

NB: 12-12-17-2 compound.

\subsection{Fertilization regime}

The study palms received uniform fertilization per palm for the first four years then uniform fertilization per unit area from the fifth year onwards (Tabs. 2a and b). The aim was to adjust the fertilizer input so that mineral nutrition was never a limiting factor. Annual leaf analyses have been used to continuously monitor the mineral nutrition status of the palms and to adjust the fertilization regime accordingly. Table 3 describes changes in nutrition data for the whole experiment from year 9 up to year 12 based on leaf contents for the main nutrients.

\subsection{Trial management}

All the replacement palms have grown satisfactorily. The causes of the replacements, especially in the first and second planting years, had nothing to do with the planting density. All the treatments have been similarly affected by the replacements. 
Table 2b. Fertilization applied since planting. Fertilization per hectare from the age of 4 years (in $\mathrm{kg}$ of fertilizer per hectare).

\begin{tabular}{|c|c|c|c|c|}
\hline \multirow[t]{2}{*}{ Date } & \multicolumn{4}{|c|}{ Type of fertilizer } \\
\hline & $\mathrm{KCl}$ & EFB & Urea & Kieserite \\
\hline 24 to 28 May 2010 & 286 & $\mathrm{x}$ & $\mathrm{x}$ & $\mathrm{x}$ \\
\hline 29 to 30 June 2011 & 357.5 & $\mathrm{x}$ & $\mathrm{x}$ & $\mathrm{x}$ \\
\hline 24 April to 16 May 2012 & $\mathrm{x}$ & 12200 & $\mathrm{x}$ & $\mathrm{x}$ \\
\hline 22 to 23 May 2012 & 286 & $\mathrm{x}$ & $\mathrm{x}$ & $\mathrm{x}$ \\
\hline 26 April to 24 May 2013 & $\mathrm{x}$ & 35000 & $\mathrm{x}$ & $\mathrm{x}$ \\
\hline 30 to 31 May 2013 & 286 & $\mathrm{x}$ & $\mathrm{x}$ & $\mathrm{x}$ \\
\hline 16 April to 14 May 2014 & $\mathrm{x}$ & 35000 & $\mathrm{x}$ & $\mathrm{x}$ \\
\hline 26 to 27 May 2014 & 357.5 & $\mathrm{x}$ & $\mathrm{x}$ & $\mathrm{x}$ \\
\hline 1 to 21 May 2015 & $\mathrm{x}$ & 35000 & $\mathrm{x}$ & $\mathrm{x}$ \\
\hline 21 to 22 May 2015 & 286 & $\mathrm{x}$ & $\mathrm{x}$ & $\mathrm{x}$ \\
\hline 16 March to 15 April 2016 & $\mathrm{x}$ & 35000 & $\mathrm{x}$ & $\mathrm{x}$ \\
\hline 21 to 22 April 2016 & $\mathrm{x}$ & $\mathrm{x}$ & $\mathrm{x}$ & 286 \\
\hline 12 to 13 May 2016 & 286 & $\mathrm{x}$ & $\mathrm{x}$ & $\mathrm{x}$ \\
\hline 19 to 20 May 2016 & $\mathrm{x}$ & $\mathrm{x}$ & 286 & $\mathrm{x}$ \\
\hline 29 March to 26 April 2017 & $\mathrm{x}$ & 35000 & $\mathrm{x}$ & $\mathrm{x}$ \\
\hline 25 to 26 April 2017 & $\mathrm{x}$ & $\mathrm{x}$ & $\mathrm{x}$ & 286 \\
\hline 10 to 12 October 2017 & 143 & $\mathrm{x}$ & $\mathrm{x}$ & $\mathrm{x}$ \\
\hline
\end{tabular}

NB: EFB = Empty Fruit Bunch.

It was possible to incorporate many of the palms replanted in 2006 (nine months after the original palms) into the population of useful palms in the ninth and tenth years after planting as they had virtually caught up with the adjacent original palms in terms of vegetative growth (stem height and foliage span) and yield. Likewise, it was possible to incorporate some of the palms replanted in 2007 (twentytwo months after the original palms) into the population of useful palms in the twelfth year after planting for the same reason, despite a larger age gap.

The replanted palms which could not be incorporated into the list of useful palms for yield calculations nonetheless played a large part of the role attributed to them by filling the gaps, thus ensuring the continuity of the canopy in accordance with the protocol density of each experimental plot.

It was thus that canopy continuity improved over time through the replacement of missing palms, with some young nursery plants in the first and second years, and by transplanting mature palms thereafter. After the age of six years, only a few one-off replacements were made. As chance would have it, the trial was not affected by lightning, which is the main cause of precision loss in a density experiment because it can kill two or three palms in one go.

\subsection{Measured variables}

Three types of variables were monitored during the second part of this experiment, namely vegetative growth, yield and climate variables.

For the vegetative growth variables:

The girth of the palms was measured at ground level each year up to stabilization, which occurred in the ninth year after planting.
Frond length was measured from the base of the petiole to the tip of the rachis each year, by adding together the linear segments.

Starting in year 7 , and then in each subsequent year, the projection on the ground of frond 33 was evaluated from the base of the stem (so, excluding the radius of the stem) to the tip of the ground projection of the frond. As frond 33 is in quite a horizontal position, its tip is considered as giving the span of the oil palm foliage, which can be viewed as a sphere. This foliage span variable was used to calculate a frond overlap rate in the canopy.

Stem height was measured from the ground to the petiole base of frond 33 each year, starting in year 6 .

Some leaf area measurements and frond counts were carried out regularly to determine the leaf area index, based on the method proposed by Tailliez and Ballo Koffi (1992).

Yield variables were also recorded. During each harvesting round (every 10 days), the number of ripe bunches per palm and the average bunch weights were recorded. Four variables were then analysed on a yearly basis, namely the bunch number per palm, average bunch weight, total bunch weight per palm and total bunch weight per hectare.

Some bunch analyses have been performed, showing a trend towards a better oil extraction rate in the highest density D6. But the number of samples is still insufficient to draw a statistically validated conclusion. Waiting for more bunch analyses, we stay focused on the two variables: number of bunches and bunch weight.

Lastly, some light interception measurements were undertaken in the second half of 2016 (Claus, 2017).

\section{Results}

Table 3 shows that the mineral nutrition of the study palms was satisfactory, as none of the analysed nutrients reached a deficiency threshold over the observation period. There was just one exception: a low period for nitrogen in December 2015 , but it was general - without any treatment effect - and was quickly corrected the following year with a urea application. In addition, mineral nutrition was found to be perfectly uniform, as no significant difference could be found between treatments for any of the analysed nutrients, apart from once for calcium in the ninth year (not shown in Tab. 3), but of no consequence as it was at high, non-limiting levels and became normal again the following year. It can be concluded that palm nutrition remained uniform and non-limiting over these four years.

Tables 4-7 show changes in the vegetative growth variables. No density treatment effect could be found for either girth or stem height. The girth of the palms stabilized in the ninth year around an average value of $265 \mathrm{~cm}$, which is within the norm of what is found at Presco, notably in some other trials under similar conditions.

Stem height increased regularly at an average rate of $35 \mathrm{~cm}$ per year over a period of 6 years, without any significant stem bolting. However, there was a growth gradient in line with planting density; it was not significant but its probability was almost significant at the $5 \%$ limit in the twelfth year. Consequently, it cannot be ruled out that significant etiolation might occur in the coming years in the high densities. This 
Table 3. Leaf contents are expressed as a weight percentage of dry matter.

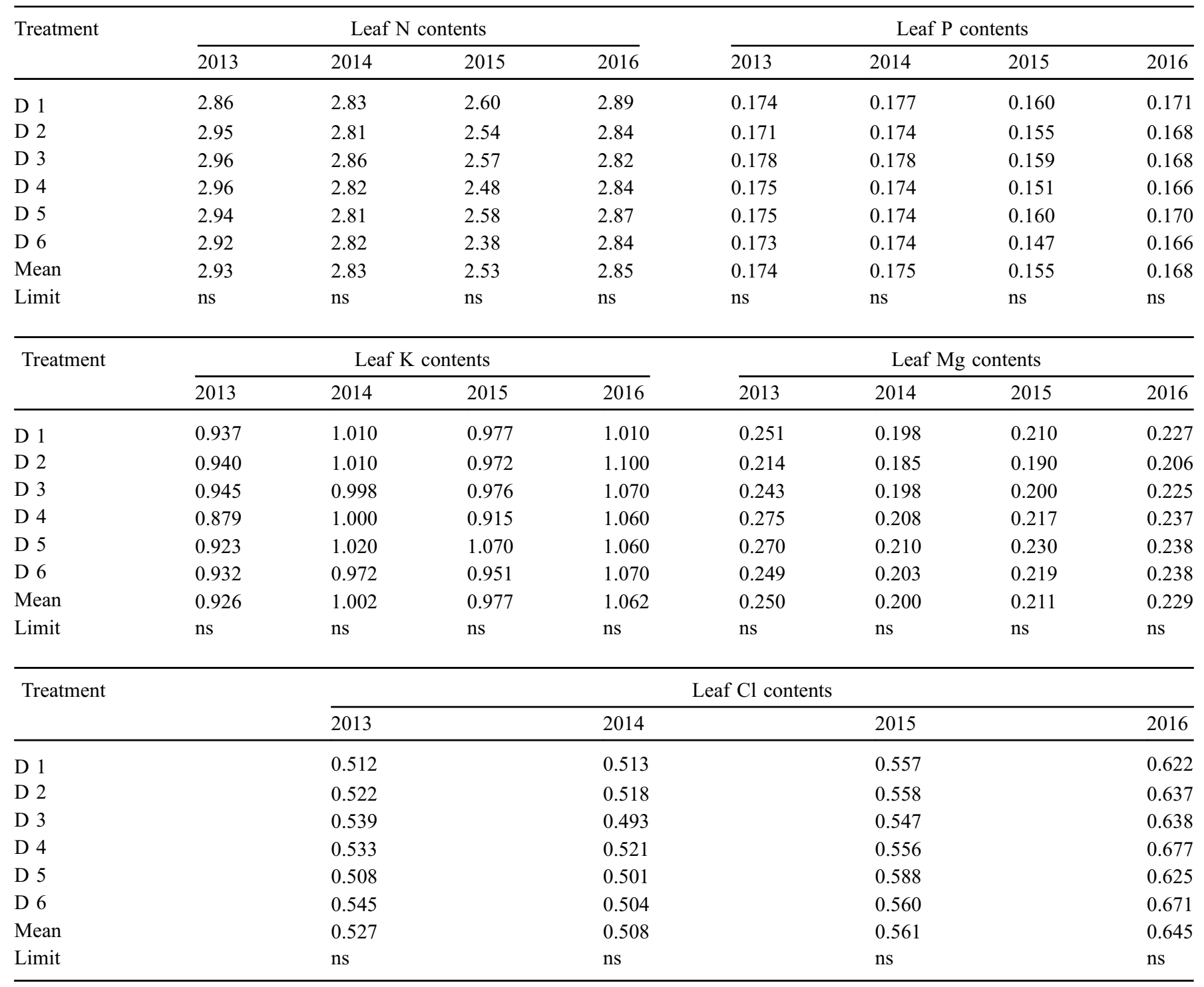

Limit $=$ significance limit; not significant $(\mathrm{ns})$ or significant under $5 \%$ or significant under $1 \%$.

$\mathrm{a}, \mathrm{b}, \mathrm{c}=$ classification of treatments according to the Tukey test at $5 \%$.

Table 4. Change in girth, in $\mathrm{m}$.

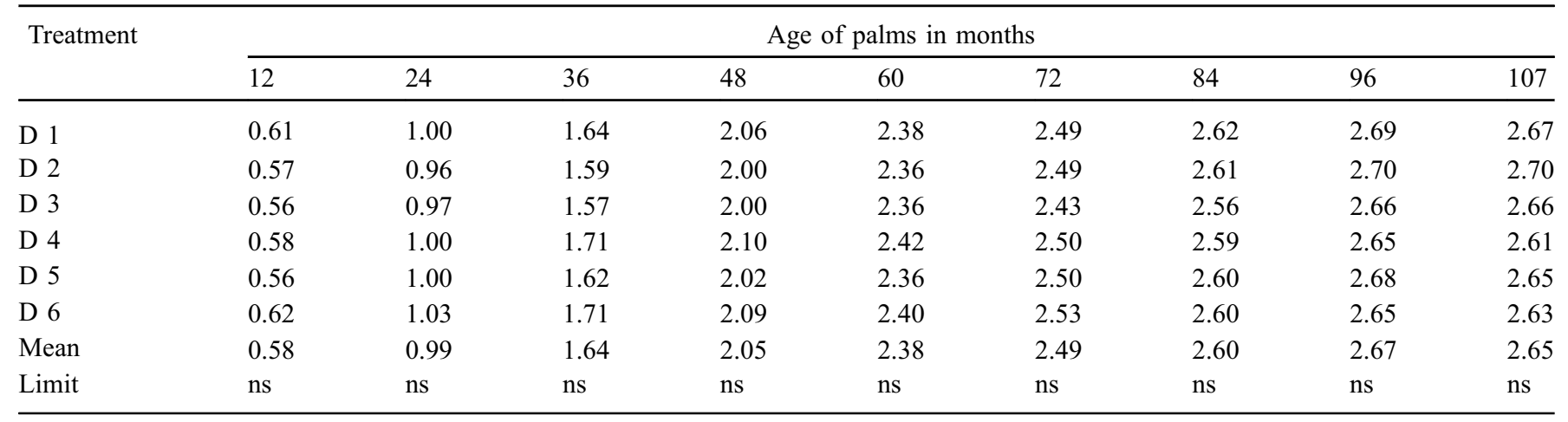

Limit $=$ significance limit; not significant $(n s)$ or significant under $5 \%$ or highly significant under $1 \%$.

$\mathrm{a}, \mathrm{b}, \mathrm{c}=$ classification of the treatments according to the Tukey test at $5 \%$. 
Table 5. Change in frond length, in $\mathrm{m}$ up to $\mathrm{m} 72$ inclusive, $\mathrm{F} 17$ from $\mathrm{m} 84$ inclusive, low frond.

\begin{tabular}{|c|c|c|c|c|c|c|c|c|c|c|c|c|}
\hline \multirow[t]{2}{*}{ Treatment } & \multicolumn{12}{|c|}{ Age of palms in months } \\
\hline & 12 & 24 & 36 & 48 & 60 & 72 & 84 & 96 & 107 & 119 & 131 & 143 \\
\hline D 1 & 1.59 & 2.34 & 3.00 & 3.87 & 4.68 & $5.20 \mathrm{bc}$ & 5.27 & $5.69 \mathrm{c}$ & $5.87 \mathrm{c}$ & $6.11 \mathrm{c}$ & $6.52 \mathrm{c}$ & $6.51 \mathrm{~b}$ \\
\hline D 3 & 1.52 & 2.26 & 3.06 & 3.85 & 4.76 & $5.25 \mathrm{abc}$ & 5.58 & $5.89 \mathrm{bc}$ & $6.12 \mathrm{abc}$ & $6.38 \mathrm{abc}$ & $6.87 \mathrm{abc}$ & $6.72 \mathrm{ab}$ \\
\hline D 4 & 1.56 & 2.30 & 3.22 & 4.04 & 4.85 & $5.50 \mathrm{ab}$ & 5.52 & $6.04 \mathrm{ab}$ & $6.18 \mathrm{ab}$ & $6.57 \mathrm{ab}$ & $7.08 \mathrm{ab}$ & $6.75 \mathrm{ab}$ \\
\hline Mean & 1.54 & 2.27 & 3.08 & 3.91 & 4.78 & 5.33 & 5.53 & 5.92 & 6.10 & 6.40 & 6.89 & 6.69 \\
\hline Limit & ns & ns & ns & ns & ns & $<0.05$ & ns & $<0.01$ & $<0.01$ & $<0.01$ & $<0.01$ & $<0.05$ \\
\hline
\end{tabular}

Limit $=$ significance limit; not significant (ns) or significant under $5 \%$ or highly significant under $1 \%$. $\mathrm{a}, \mathrm{b}, \mathrm{c}=$ classification of the treatments according to the Tukey test at $5 \%$.

Table 6. Change in stem height, in $\mathrm{m}$.

\begin{tabular}{llllllll}
\hline \multirow{2}{*}{ Treatment } & \multicolumn{7}{c}{ Age of palms in months } \\
\cline { 2 - 8 } & 72 & 84 & 96 & 107 & 119 & 131 & 143 \\
\hline D 1 & 0.81 & 1.08 & 1.38 & 1.76 & 2.21 & 2.44 & 2.82 \\
D 2 & 0.84 & 1.11 & 1.40 & 1.75 & 2.23 & 2.57 & 2.89 \\
D 3 & 0.83 & 1.09 & 1.42 & 1.78 & 2.22 & 2.57 & 2.90 \\
D 4 & 0.87 & 1.14 & 1.48 & 1.86 & 2.34 & 2.67 & 3.05 \\
D 5 & 0.83 & 1.02 & 1.38 & 1.74 & 2.23 & 2.61 & 2.96 \\
D 6 & 0.88 & 1.15 & 1.45 & 1.84 & 2.28 & 2.62 & 3.09 \\
Mean & 0.84 & 1.10 & 1.42 & 1.79 & 2.25 & 2.58 & 2.95 \\
Limit & ns & ns & ns & ns & ns & ns & ns \\
\hline
\end{tabular}

Limit $=$ significance limit; not significant (ns) or significant under $5 \%$ or highly significant under $1 \%$.

etiolation phenomenon in high densities is often seen in oil palm plantations (Taniputra et al., 1985 quoted by Donough and Kwan, 1991).

Frond length continued to increase up to year 11 after planting and a gradient could be seen: the closer together the palms were planted, the longer the fronds were. But the number of fronds per palms as measured in 2016 by Claus (2017) follows the opposite trend: decreasing in line with the planting density: from 34,4 (D1) down to 30,8 (D6).

The same applied for the foliage span of the oil palms (distance from the stem of the vertical projection on the ground of a horizontal frond). The average span at 12 years was found to be $6.05 \mathrm{~m}$.

It cannot be confirmed that the foliage span of the oil palms has peaked at 12 years. It cannot be ruled out that the fronds will continue to lengthen, which would mean that competition between the palms for light interception will increase further, to the detriment of yield in the high densities.

Tables $8-11$ and Figures 2 and 3 provide production data compiled from 10 harvesting campaigns (years 3 to 12).

While the high densities were still largely ahead in terms of cumulative yield at the end of the eighth year (Bonneau et al., 2014), they fell back considerably between the ninth and
Table 7. Change in the distance from the stem of the projection on the ground of the tip of frond 33 , in $\mathrm{m}$.

\begin{tabular}{lllllll}
\hline \multirow{2}{*}{ Treatment } & \multicolumn{6}{c}{ Age of palms in months } \\
\cline { 2 - 7 } & 84 & 96 & 107 & 119 & 131 & 143 \\
\hline D 1 & 4.69 & $4.86 \mathrm{~b}$ & 5.08 & 5.54 & $5.48 \mathrm{~b}$ & $5.89 \mathrm{~b}$ \\
D 2 & 4.70 & $4.94 \mathrm{~b}$ & 5.20 & 5.63 & $5.57 \mathrm{ab}$ & $5.96 \mathrm{ab}$ \\
D 3 & 4.77 & $5.05 \mathrm{ab}$ & 5.25 & 5.71 & $5.72 \mathrm{ab}$ & $6.14 \mathrm{ab}$ \\
$\mathrm{D} 4$ & 4.92 & $5.16 \mathrm{a}$ & 5.37 & 5.79 & $5.87 \mathrm{a}$ & $6.05 \mathrm{ab}$ \\
$\mathrm{D} \mathrm{5}$ & 4.85 & $5.19 \mathrm{a}$ & 5.29 & 5.73 & $5.78 \mathrm{ab}$ & $6.05 \mathrm{ab}$ \\
D 6 & 4.93 & $5.22 \mathrm{a}$ & 5.42 & 5.85 & $5.90 \mathrm{a}$ & $6.22 \mathrm{a}$ \\
Mean & 4.81 & 5.07 & 5.27 & 5.71 & 5.72 & 6.05 \\
Limit & $\mathrm{ns}$ & $<0.01$ & $\mathrm{~ns}$ & $\mathrm{~ns}$ & $\mathrm{~ns}$ & $<0.05$ \\
\hline
\end{tabular}

Limit $=$ significance limit; not significant (ns) or significant under 5\% or highly significant under $1 \%$.

twelfth years after planting. The competition effect increased due to the regular rise in vegetative bulk. Table 12 reveals the gradual increase in foliage overlap with time. At the end of the twelfth year after planting, $88 \%$ of the area was covered by the foliage of two or three palms in treatment D6 as opposed to $37 \%$ only in treatment D1. There is reason to believe that competition for PAR interception is highly correlated to foliage bulk.

The light interception and leaf area measurements carried out in 2016 (Claus, 2017) gave the following results:

The light interception percentage varied from 85.2 (D1) to 93.9 (D6), rising in line with the planting density.

The leaf area index at 11 years varied from 3.24 (D1) to 4.81 (D6) growing in line with the planting density. This result is below the norm of 5 to 6 in the oil palm like in Gerritsma and Soebagyo (1999) but Hardon et al. (1969), Lamade and Setiyo (1996) and Perez (2017) found that the leaf area index of the oil palm could vary within a wide range (3 to 6), notably depending on the type of planting material, the location (higher in South East Asia than West Africa) and pruning intensity. Figure 2 shows the change in the yield ratio of the treatments in line with that of the control density D1. It can be seen that the gap continually shrinks over time. This is perfectly normal, as 
Table 8. Change in annual yield per palm in $\mathrm{kg}$ of bunches.

\begin{tabular}{|c|c|c|c|c|c|c|c|c|c|c|}
\hline Treatment & \multicolumn{10}{|c|}{ Year of planting } \\
\hline D 1 & $2.5 \mathrm{ab}$ & 27.2 & 34.7 & 81.0 & 70.0 & $110.2 \mathrm{ab}$ & $125.1 \mathrm{a}$ & $135.9 \mathrm{a}$ & $132.6 \mathrm{a}$ & $148.8 \mathrm{a}$ \\
\hline D 3 & $1.7 \mathrm{bc}$ & 29.9 & 36.6 & 75.3 & 64.6 & $109.9 \mathrm{ab}$ & $112.0 \mathrm{ab}$ & $122.0 \mathrm{a}$ & $125.3 \mathrm{ab}$ & $122.0 \mathrm{ab}$ \\
\hline D 4 & $3.0 \mathrm{a}$ & 34.4 & 33.6 & 74.2 & 56.9 & $98.9 \mathrm{bc}$ & $83.6 \mathrm{~cd}$ & $106.4 \mathrm{ab}$ & $102.7 \mathrm{bc}$ & $103.2 \mathrm{bc}$ \\
\hline Mean & 2.2 & 30.8 & 34.1 & 73.9 & 62.0 & 103.0 & 102.1 & 115.1 & 114.9 & 119.2 \\
\hline Limit & $<0.01$ & $\mathrm{~ns}$ & ns & ns & ns & $<0.05$ & $<0.01$ & $<0.01$ & $<0.01$ & $<0.01$ \\
\hline
\end{tabular}

Limit $=$ limit of significance; not significant $(\mathrm{ns})$ or significant under $5 \%$ or highly significant under $1 \%$.

$\mathrm{a}, \mathrm{b}, \mathrm{c} . . .=$ classification of the treatments according to the Tukey test at $5 \%$.

Table 9. Change in cumulative yield per palm in $\mathrm{kg}$ of bunches.

\begin{tabular}{|c|c|c|c|c|c|c|c|}
\hline Treatment & \multicolumn{7}{|c|}{ Year of planting } \\
\hline D 1 & 146 & 215 & 326 & $451 \mathrm{a}$ & $587 \mathrm{a}$ & $719 \mathrm{a}$ & $868 \mathrm{a}$ \\
\hline D 3 & 144 & 208 & 318 & $430 \mathrm{ab}$ & $552 \mathrm{ab}$ & $677 \mathrm{abc}$ & $799 a b$ \\
\hline D 4 & 145 & 202 & 301 & $385 \mathrm{bc}$ & $491 \mathrm{bc}$ & $594 \mathrm{~cd}$ & $697 \mathrm{~cd}$ \\
\hline Mean & 141 & 203 & 306 & 408 & 523 & 638 & 757 \\
\hline Limit & ns & ns & ns & $<0.01$ & $<0.01$ & $<0.01$ & $<0.01$ \\
\hline
\end{tabular}

Limit $=$ limit of significance; not significant (ns) or significant under $5 \%$ or highly significant under $1 \%$.

Table 10. Change in annual yield per unit area in tons of bunches per hectare.

\begin{tabular}{|c|c|c|c|c|c|c|c|c|c|c|}
\hline Treatment & \multicolumn{10}{|c|}{ Year of planting } \\
\hline D 1 & $0.32 \mathrm{~b}$ & $3.48 \mathrm{~d}$ & 4.44 & 10.37 & 8.98 & $14.11 \mathrm{~b}$ & 16.01 & 17.40 & 16.97 & 19.05 \\
\hline D 2 & $0.21 \mathrm{~b}$ & $3.93 \mathrm{~cd}$ & 5.12 & 11.35 & 8.75 & $16.36 \mathrm{ab}$ & 16.86 & 17.58 & 17.91 & 20.05 \\
\hline D 3 & $0.27 \mathrm{~b}$ & $4.78 \mathrm{bcd}$ & 5.86 & 12.05 & 10.34 & $17.59 \mathrm{a}$ & 17.92 & 19.52 & 20.05 & 19.53 \\
\hline D 4 & $0.54 \mathrm{a}$ & $6.19 \mathrm{ab}$ & 6.04 & 13.35 & 10.23 & $17.80 \mathrm{a}$ & 15.04 & 19.16 & 18.49 & 18.57 \\
\hline Mean & 0.36 & 5.19 & 5.62 & 12.13 & 10.18 & 16.89 & 16.08 & 18.28 & 18.21 & 18.79 \\
\hline Limit & $<0.01$ & $<0.01$ & ns & ns & ns & $<0.05$ & ns & $\mathrm{ns}$ & $\mathrm{ns}$ & $\mathrm{ns}$ \\
\hline
\end{tabular}

Limit = limit of significance; not significant (ns) or significant under $5 \%$ or highly significant under $1 \%$.

$\mathrm{a}, \mathrm{b}, \mathrm{c} . . .=$ classification of the treatments according to the Tukey test at $5 \%$.

the older the young palms become, the more they increase their leaf area and the more the effect of competition for light interception increases following an increasing gradient in line with the planting density.

It therefore needs to be known whether that trend will continue over time and if so, for how much longer.
To gain a clearer picture, Figure 3 focuses on the last 4 years, between the ninth and twelfth year after planting. A regular drop can be seen in the three treatments D4, D5 and D6, stabilization in treatment D2 and, after three years with a stable cumulative yield, a one-off downturn in the twelfth year for treatment D3. 
Table 11. Change in cumulative yield per unit area in tons of bunches per hectare.

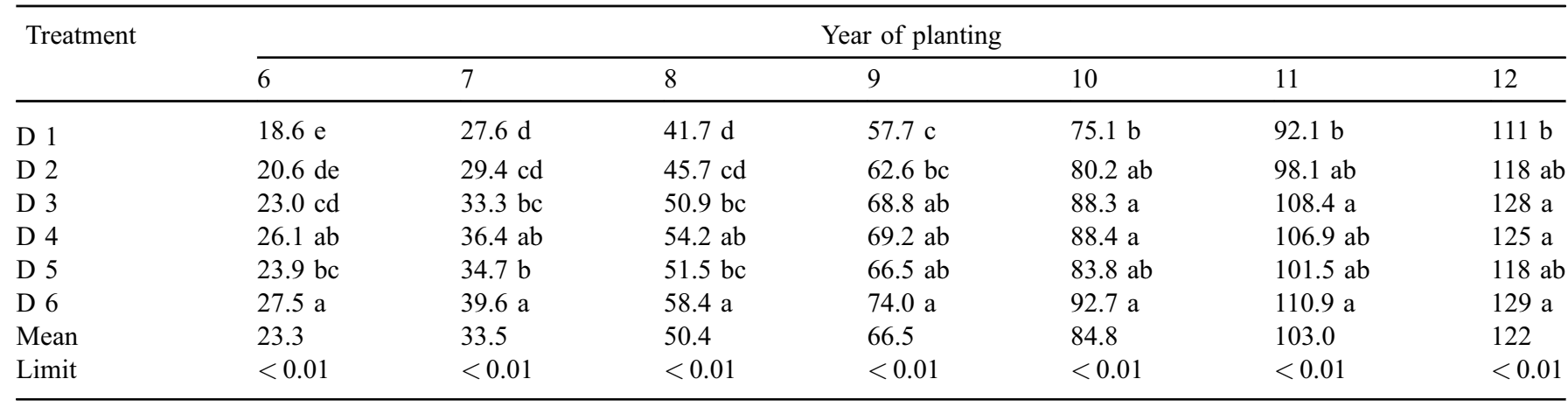

Limit $=$ limit of significance; not significant $(\mathrm{ns})$ or significant under $5 \%$ or highly significant under $1 \%$. $\mathrm{a}, \mathrm{b}, \mathrm{c} . . .=$ classification of the treatments according to the Tukey test at $5 \%$.

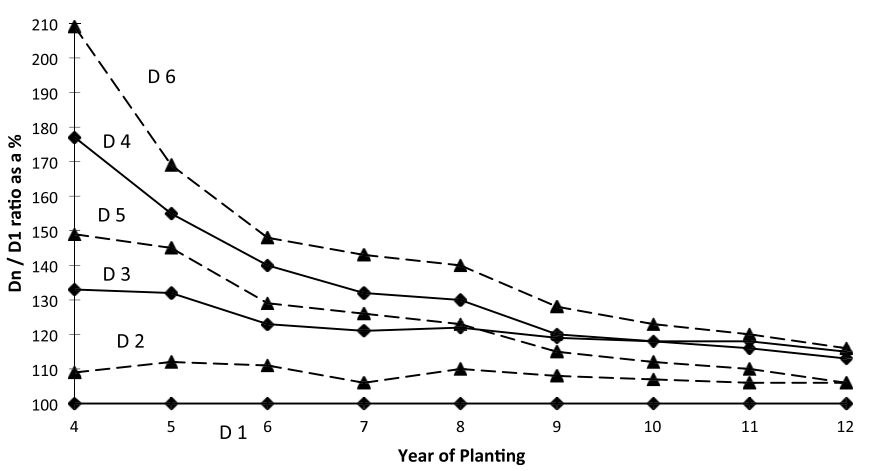

Fig. 2. Annual variation in the Dn / D1 cumulative yield ratio.

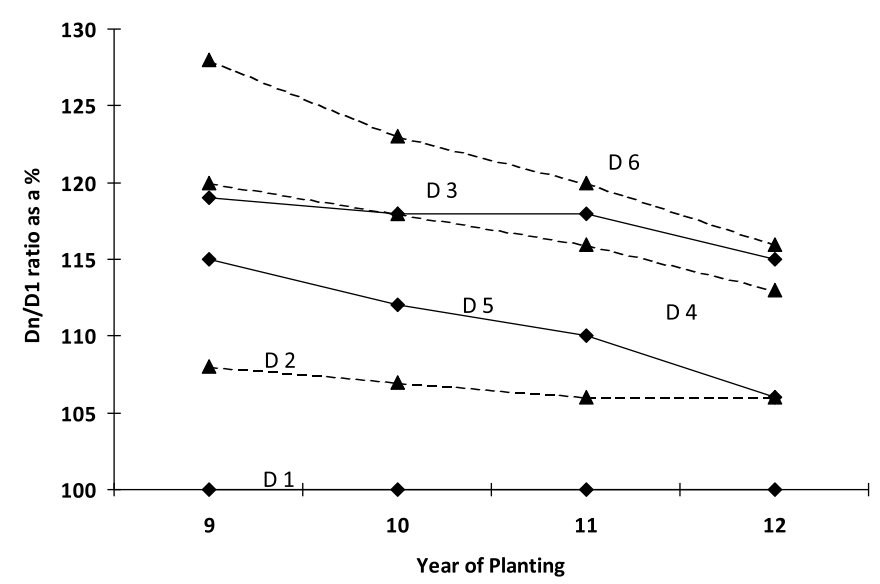

Fig. 3. Changes in the Dn/D1 ratio during the last four seasons.

\section{Discussion}

The first point concerns thinning (a comparison between treatments D4 and D5). Four years after the operation (remember that this consisted in eliminating every seventh palm in the middle of each hexagon in treatment D5) no significant effect on palm yields was found: there was a very slight increase in yield for D5 compared to D4, but it was not significant and was far too small to compensate for the loss of a seventh of the palms.

Consequently, the annual yield in treatment D5 remained constantly below the annual yield in treatment D4. There was no sign of catching up. It was therefore concluded that under these experimental conditions, thinning did not bring the expected advantages. Nazeeb et al. (1990) showed that thinning brings advantages in particular conditions only, as: early thinning from a very high initial planting density and at 5 year term. Corley et al. (1973) quoted by Donough and Kwan (1991) added another disadvantage: through thinning, the initial planting design in equilateral triangles, which is optimum for light interception, is always lost.

The second point is the comparison of the five treatments without thinning: D1, D2, D3, D4 and D6. Initially, a projection in time was established on the basis of the results obtained so far, using different types of mathematical fitting, including two assumed to be the most appropriate, i.e. both sticking as closely as possible to the points actually obtained and eventually resulting in a baseline asymptote:

-The logistic model of equation $y=a /\left(1-b^{*} e^{-c^{*} x}\right)$

-The saturation growth model of equation $y=a * x /(x-b)$

( $\mathrm{a}, \mathrm{b}$ and $\mathrm{c}$ being actual positive coefficients)

The results are shown in Table 13: extension in time up to the asymptote with the logistic regression model or with the saturation growth model. The saturation growth model complies more than the logistic model with the trends seen so far in the final order of the treatments, seeming to give a slight advantage to D3 over D2, but there is still too much imprecision to decide between the two.

Indeed, it can be seen among the high densities (treatments D4 and D6) that the Dn/D1 ratio in cumulative yield compared to that in the control D1 continued to fall year after year, for nine years of continued yield records. This result is in line with common sense as already explained and confirmed by certain authors (Donough et al., 1991): the more oil palms increase in age, the more competition increases to the detriment of high densities, at least until the palms reach their maximum foliage span. For instance, Figure 4 shows that, in cumulative data, the optimum density point decreases over time. However, there are 
Table 12. Change in oil palm foliage bulk.

\begin{tabular}{llllllll}
\hline & & & \multicolumn{4}{c}{ Foliage span (metre) } \\
\cline { 4 - 7 } & Age of palms (year) & & 7 & 8 & 9 & 10 & 11 \\
\hline D 1 & 128 & 9.5 & 4.69 & 4.86 & 5.08 & 5.54 & 5.48 \\
D 2 & 143 & 9 & 4.70 & 4.94 & 5.20 & 5.63 & 5.57 \\
D 3 & 160 & 8.5 & 4.77 & 5.05 & 5.25 & 5.71 & 5.72 \\
D 4 & 180 & 8 & 4.92 & 5.16 & 5.37 & 5.79 & 5.87 \\
D 6 & 205 & 7.5 & 4.93 & 5.22 & 5.42 & 5.85 & 5.90 \\
Treatment & Density & Distance & & & & & 6.05 \\
& & & & & & &
\end{tabular}

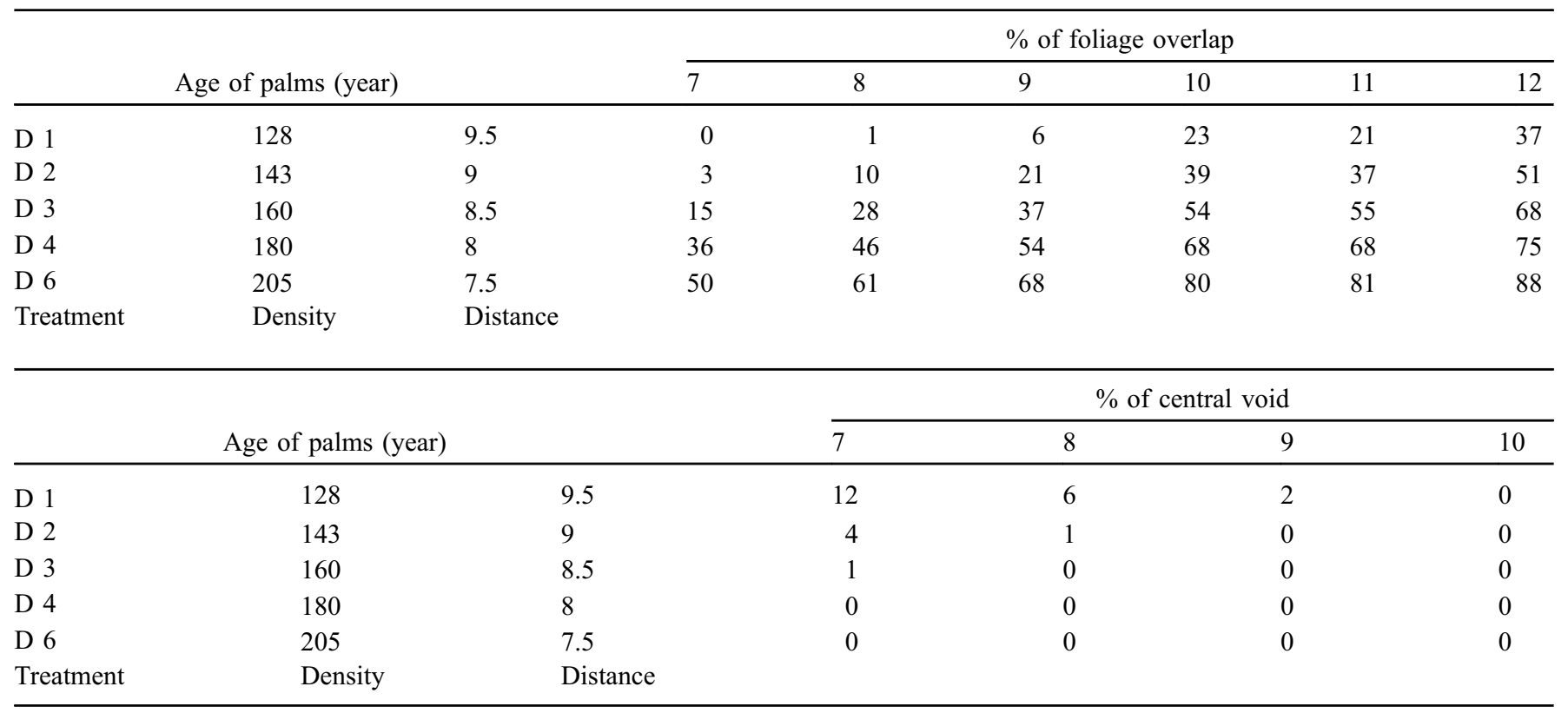

Foliage span = the distance (in $\mathrm{m}$ ) from the bole to the projection on the ground of the tip of frond 33 .

Percentage of foliage overlap = by projection of the foliage volume (assimilated to a sphere) on a plane.

Part of the area of a unit triangle covered by the foliage of 2 or 3 palms (trigonometric determination).

Table 13. Extension of the curves in Figure 2 by two different models.

\begin{tabular}{llc}
\hline & \multicolumn{2}{c}{ End value } \\
\cline { 2 - 3 } Dn / D1 & Logistic model & Saturation growth model \\
\hline D 6 & 114 & 98 \\
D 4 & 107 & 97 \\
D 3 & 114 & 109 \\
D 2 & 63 & 105
\end{tabular}

Logistic model $y=a /\left(1+b * e \exp \left(-c^{*} x\right)\right)$.

Saturation growth model $\mathrm{y}=\mathrm{a} * \mathrm{x} /(\mathrm{x}-\mathrm{b})$.

$\mathrm{a}, \mathrm{b}$ and $\mathrm{c}=$ positive coefficients.

The saturation model is more realistic.

still not enough points to apply a fitting function that gives a sufficiently precise value at the end of the cycle (between 20 and 25 years).

All that can be assumed is that the trend will continue in the future. This has even more chance of happening in that the foliage bulk has continued to increase and may not have

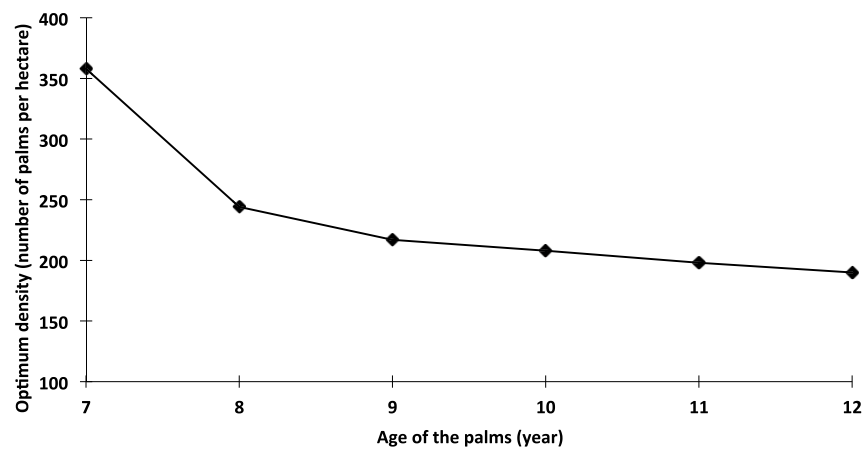

Fig. 4. Optimum density versus age.

reached its maximum yet. Competition for light interception in the coming years is therefore going to be just as strong as in the twelfth year and maybe even stronger.

It is therefore reasonable to assume that the relative cumulative yield in treatments D4 and D6 will continue to decrease, eventually falling below those of the lower density treatments (this is already happening compared to treatment 
D3). The hypothesis put forward is therefore that a planting density over $160 \mathrm{p} / \mathrm{ha}$ is excessive.

On the other hand, the relative yield has been stable for several years in treatment $\mathrm{D} 2:+6 \%$ compared to the control D1. The hypothesis put forward is therefore that the trend will continue unchanged - or hardly changed - in the coming years and up to the end of the cycle.

The situation for treatment $\mathrm{D} 3$ is intermediate. The relative cumulative yield remained more or less stable up to the eleventh year, then there was a sudden drop of three points in year twelve. On this basis, two scenarios can be imagined.

Firstly, the decline continues at the same rate in the future and treatment D3 then follows the model of treatments D4 and D6, namely that eventually, before the end of the 25-year planting cycle in any case, it will fall below treatments $\mathrm{D} 2$ then D1. The planting density of $160 \mathrm{p} / \mathrm{ha}$ will then be considered excessive and the optimum will be nearer the planting density of $143 \mathrm{p} / \mathrm{ha}$.

Secondly, the decrease seen in the twelfth year corresponds to an "accident" in a general process of stabilization and treatment D3 will stabilize again at a level above that of treatment D2. In this event, it is the $160 \mathrm{p} /$ ha planting density that will be declared optimum.

It can therefore be seen, based on the reasonable hypotheses that can be put forward, that at the end of the twelfth year after planting the choice will be between 143 and $160 \mathrm{p} / \mathrm{ha}$. This is a range of variation that is compatible with those determined by some other authors using locallyproduced materials: $140 \mathrm{p} /$ ha (Prévôt and Duchesne, 1955), $170 \mathrm{p} / \mathrm{ha}$ (Corley and Tinker, 2016) in West Africa, 143 to $185 \mathrm{p} / \mathrm{ha}$ (Donough and Kwan, 1991), 136 to $148 \mathrm{p} / \mathrm{ha}$ in Malaysia (Nazeeb et al., 2007).

Moreover, a third scenario, between the first two, might occur, i.e. a slight and gradual drop in treatment D3, reaching a value similar to that of D2 by the end of the cycle. In this case, it is not an optimum density point that will be reached at the top of the quadratic fit curve, but rather a highly flattened bell in the form of a plateau where there will not be a particular point but rather an optimum density segment.

\section{Conclusion}

We can draw conclusions based on data recorded over the last twelve years, including yield data for nine years running, and on likely scenario simulations.

Under our local experimental conditions, the optimum planting density would appear to be between 143 and $160 \mathrm{p} / \mathrm{ha}$. It will take a few more years to be more precise, bearing in mind that a plateau may also be reached.

As a precaution, we can therefore recommend for the time being that this $\mathrm{C} 1001 \mathrm{~F}$ planting material from Pobè should be planted at $143 \mathrm{p} / \mathrm{ha}$ under similar conditions, i.e. on ferralitic soils in the West Africa coastal zone. However, there would be no harm in planting at $160 \mathrm{p} / \mathrm{ha}$, given that both treatments have a good chance of ending the cycle on similar cumulative yield values.

If a plateau is reached, then other factors than the pure agronomic one have to be taken into account to determine the optimal planting density, mainly the economic factor. As mentioned by Prévôt and Duchesne (1955), the economic optimal density is always a bit lower than the agronomic optimal density, because at equivalent productivity, planting more trees per hectare infers additional costs: more trees to maintain, to fertilize and to harvest per unit area.

In our case, if it happens that the agronomic productivity is equivalent, then planting at $143 \mathrm{p} / \mathrm{ha}$ would be a better choice than planting at $160 \mathrm{p} / \mathrm{ha}$.

It will be worth homing in on the optimum density with greater precision by testing different densities covering the 143-160 plateau range. For example, we could propose a new trial testing planting densities such as $135-143-151-160$ - $170 \mathrm{p} / \mathrm{ha}$ corresponding to $9.25-9-8.75-8.5-8.25$ metres between palms in an equilateral triangle design, respectively.

We could also use the morphological characteristics, which are being studied in the present trial to make 3D simulations of what could happen in a narrower range of planting densities around the optimum.

In addition to this main result, we were able to show that thinning, as carried out here, did not lead to any agricultural advantage (no increase in yield in four years). Given that thinning entails an extra cost compared to a constant density (the cost of felling or poisoning the palms to be eliminated), and that it wipes out the advantage of an optimum canopy architecture for light interception, we advise against this technique. It is preferable to plant an oil palm plot at the assumed optimum density and to keep that density throughout the cycle.

Under our experimental conditions, the optimum density (estimated at $160 \mathrm{p} /$ ha pending confirmation) corresponds to a Leaf Area Index of 4, an overlap rate of $68 \%$ and a light interception rate of $90 \%$, as measured and calculated in the twelfth planting year.

\section{References}

Bonneau X, Vandessel P, Buabeng M, Erhahuy C. 2014. Early impact of oil palm planting density on vegetative and oil yield variables in West Africa. OCL 21(4): A401.

Claus G. 2017. Plandichtheid versus lichtinterceptie bij oliepalm (Elaieis guineensis Jacq.) Een gevaltstudie uit Nigeria. Mémoire de mastère soutenu en juin 2017 à l'université de Gand (Belgique): 55 pages.

Corley R, Tinker P. 2016. The Oil Palm, 5th ed. Chichester, West Sussex, UK: John Wiley and Sons, 680 p. ISBN: 978-1-11895330-3.

Donough C, Kwan B. 1991. Oil palm planting density: results from trials in Sabah and possible options. Planter 67(787): 483-506.

Gerritsma W, Soebagyo F. 1999. An analysis of the growth of the leaf area of oil palms in Indonesia. Exp Agric 35(03): 293-308.

Hardon JJ, William CN, Watson I. 1969. Leaf area and yield in the oil palm in Malaya. Exp Agric 1969(05): 25-32.

Lamade E, Setiyo IE. 1996. Test of Dufrêne's production model on two contrasting families of oil palm in North Sumatra. Proceedings of PORIM International Palm Oil Congress Agriculture, Kuala Lumpur, Malaysia, 427-433.

Nazeeb M, Loong S, Goh K, Wood B. 1990. Trials on planting oil palms at high initial densities with later thinning. PORIM International Palm Oil Development Conference Agriculture, Kuala Lumpur, Malaysia, 5 to 9 September 1989.

Nazeeb M, Loong S, Barakbah Tang M. 2007. Variable density plantings for oil palms (Elaeis guineensis) in Peninsular Malaysia. PIPOC International Palm Oil Congress. Empowering Change. Kuala Lumpur, Malaysia, MPOB, 26 to 30 August, 2007. 
Perez R. 2017. Analyzing and modelling the genetic variability of aerial architecture and light interception of oil palm (Elaeis guineensis Jacq.). Mémoire de doctorat soutenu au Cirad à Montpellier (France) en janvier 2017: 147 p.
Prévôt P, Duchesne J. 1955. Densités de plantation pour le palmier à huile. Oléagineux 10(2): 117-122.

Tailliez B, Ballo Koffi C. 1992. A method for measuring oil palm leaf area. Oléagineux 47(8-9): 537-545.

Cite this article as: Bonneau X, Impens R, Buabeng M. 2018. Optimum oil palm planting density in West Africa. OCL 25(2): A201. 